численности $\mathrm{B}$-лимфоцитов, Т-хелперов и регуляторных $\mathrm{CD}^{+} \mathrm{CD} 25^{+}$-клеток. Иммунорегуляторный индекс (CD4/CD8) снижен. В ПКВ 38-40 недель количество В-клеток увеличивается и не отличается от аналогичного показателя детей с PH I-II стадии, однако, сохраняется сниженное содержание Т-хелперов и $\mathrm{CD} 4^{+} \mathrm{CD} 25^{+}$-лимфоцитов.

В показателях врожденного иммунитета регистрируется снижение уровня экспрессии молекул адгезии на моноцитах пуповинной крови (CD64CD14), которое сохраняется в течение неонатального периода и в ПКВ 38-40 недель. Также в этот период у детей с пороговой ретинопатией отмечается повышенное содержание CD14 ${ }^{+} \mathrm{HLA}_{\mathrm{L}} \mathrm{DR}^{+}-$моноцитов и абсолютное количество натуральных киллеров.

Статья подготовлена при финансовой поддержке Минобрнауки, грант Президента Российской Федерациии № МК-1140.2020.7.

$* * *$

1. Smith L.E.H. Pathogenesis of retinopathy of prematurity. Semin.Neonatol. 2003; 8: 469-73

2. Катаргина Л.А. Ретинопатия недоношенных, современное состояние проблемы и задачи организации офтальмологической помощи недоношенным детям в РФ. Российская педиатрическая офтальмология. 2012; 1: $5-7$

3. International Committee for the Classification of Retinopathy of Prematurity. The international classification of retinopathy of prematurity revisited. Arch. Ophthal. 2005; 123: 991-9

4. Aikawa H., Noro M. Low incidence of sight-threatening retinopathy of prematurity in infants born before 28 weeks gestation at a neonatal intensive care unit in Japan. Tohoku J. Exp. Med. 2013;230 (3): 185-90

5. Катаргина Л.А., Слепова О.С., Демченко Е.Н., Осипова Н.А. Роль системного дисбаланса цитокинов в патогенезе ретинопатии недоношенных Российская педиатрическая офтальмология, № 4, 2015 С.16-19

6. Sood B.G., Madan A., Saha Sh., Schendel D., Thorsen P., Skogstrand K. et al. Perinatal systemic inflammatory response syndrome and retinopathy of prematurity. Pediatr. Res. 2010; 67 (4): 394-400

7. Silveira R.C., Fortes Filho J.B., Procianoy R.S. Assessment of the contribution of cytokine plasma levels to detect retinopathy of prematurity in very low birth weight infants. Invest. Ophthalmol. Vis. Sci. 2011; 52 (3): 1297-301

\title{
Ходосевич А.А., Ефременко Е.С. \\ Оценка выраженности дисмутации супероксидного анион-радикала в воспалительную фазу течения полнослойного повреждения кожи
}

ФГБОУ ВО «Омский государственный медицинский университет»

(Россия, Омск)

doi: 10.18411/trnio-10-2021-101

\section{Аннотация}

В работе представлены сведения об уровне активности супероксиддисмутазы раневого отделяемого при эксперименте по формированию полнослойного повреждения кожных покровов. Показана тенденция к уменьшению активности исследуемого показателя. Обсуждаются вероятные факторы, определяющие модификацию энзиматической активности.

Ключевые слова: кожа, рана, повреждение, травма, хирургия, воспаление, свободные радикалы, антиоксиданты, ферменты, СОД.

\section{Abstract}

The paper presents information about the level of superoxide dismutase activity in an experiment on the formation of full-layer damage to the skin. The tendency to decrease the activity of the studied indicator is shown. The factors determining the modification of enzymatic activity are discussed.

Keywords: skin, wound, injury, trauma, surgery, inflammation, free radicals, antioxidants, enzymes, SOD. 
Актуальность исследования. В большинстве случаев развитие травм различной этиологии сопровождается возникновением нарушений целостности кожи. При этом, для раневого процесса характерно фазовое течение, которое выражается как общим компенсаторным ответом на повреждение, так и локальными тканевыми реакциями. Имеющиеся сведения о местных изменениях тканей в области поражения позволяет рассматривать их в качестве частного случая патологического процесса - воспалительной реакции.

Принято считать, что обязательным молекулярным событием, в данном случае, является активация свободнорадикальных процессов, сопряженная с перемещением фагоцитов в зону повреждения. Свободнорадикальная продукция, осуществляемая указанными клетками, требуется для предотвращения присоединения бактериальной инфекции. В связи с этим, значимым аспектом может быть уровень генерации свободных радикалов. Так, низкий уровень образования радикалов предопределяет расширение очага воспаления за счет активности бактериальных клеток. Наоборот, повышенный, избыточный уровень радикалообразования может приводить к более длительному течению асептического воспаления и повышению сроков восстановления повреждённого участка.

Немаловажным моментом, определяющим выраженность формирования свободнорадикальных субстанций, является работа энзиматической составляющей антиоксидантной системы организма, первая линия которой представлена супероксиддисмутазой. Выяснение уровня активности указанного фермента позволит составить представление о необходимости таргетного терапевтического воздействия.

Цель работы. Определение уровня активности супероксиддисмутазы при полнослойной, плоскостной ране кожных покровов на раннем этапе формирования раневого процесса для создания представления о выраженности антиоксидантного местного ответа и необходимости метаболической коррекции.

Материалы и методы. У 30 нелинейных белых крыс массой 120-180г экспериментально моделировали формирование полнослойной, плоскостной раны удалением части кожного покрова (площадь=200 мм2). Выяснение состояния антиоксидантной защиты проводили путем измерения уровня активности супероксиддисмутазы раневого отделяемого [4]. Показателями описательной статистики были: медиана (Me), верхний $(\mathrm{H})$ и нижний (L) квартили. Оценку статистической значимости различий проводили путем применения непараметрического критерия Вилкоксона (W) для связанных выборок [3].

Результаты и их обсуждение. В ходе проведения эксперимента была установлена тенденция к уменьшению супероксиддисмутазной активности раневого отделяемого через трое суток после механического нарушения структуры кожных покровов. Активность фермента в данный срок исследования составила 23,51 $(19,62 ; 25,94)$ ед. акт.

Третьи сутки течения раневого процесса рекомендуется рассматривать, как раннюю стадию развития типового патологического процесса - воспаления. Общепризнанно, что важнейшим звеном его патогенеза является усиление продукции веществ свободнорадикального характера, что обуславливает изменения структуры главных молекул организма: протеинов, высших жирных кислот, фосфолипидов, ДНК и РНК. Основным фактором, определяющим формирование свободных радикалов в данный период, является каталитическая активность НАДФН-оксидазы (КФ 1.6.99.6) фагоцитирующих клеток. Литературные данные, посвященные строению и функционированию указанного фермента, свидетельствуют о том, что он представляет собой ферментативную систему, осуществляющую реакцию восстановления молекулярного кислорода до воды с параллельным образованием радикала супероксида.

Механизмы защиты от влияния супероксидного анион-радикала в отношении интактных тканей организма могут быть связаны с: а) локализацией фермента в зоне, которая отделена от окружающих тканей мембраной фагоцита; б) наличием механизма самоинактивации энзима, что отражается на строго определенном времени его работы; в) расположением ферментных субъединиц в различных клеточных компартментах; г) 
модификацией взаимодействий между липидными и белковыми соединениями, ведущей к изменению ферментативной активности.

Запуск самосборки ферментативного комплекса НАДФН-оксидазы происходит при активировании клеток фагоцитарного ряда. Правильное взаиморасположение мембранных и цитозольных структур комплекса опосредует трансмембранный перенос электрона на молекулу кислорода с высвобождением в качестве продукта аниона супероксида.

Классификация веществ свободнорадикального характера относит супероксидный анион-радикал к категории активированных кислородных метаболитов, кислородных радикалов. Анионная природа радикала обуславливает его пониженные способности к транспорту через клеточные и субклеточные мембраны. Отмечается, что его действие, прежде всего, связано с возможностью восстановительных реакций относительно различных соединений. К продуцентам супероксида также относятся следующие ферменты: монооксигеназы мембран эндоплазматической сети, ксантиноксидоредуктаза и оксидаза цитохрома с.

Интенсификация пролиферации лимфоцитов, повышение адгезивных свойств клеток гранулоцитарного ряда в отношении сосудистого эндотелия, формирование хемотаксических факторов пептидного строения - главные естественные эффекты радикала супероксида при развитии воспалительной реакции. Роль супероксида, как стартового компонента для генеза прочих активных форм кислорода, определяет его опосредованную микробицидную активность. Повышенное образование свободнорадикальных веществ представляется физиологической адаптивной реакцией организма в ответ на нарушение его структур. При этом, следует учитывать, что превышение определенного уровня свободных радикалов будет нести опасность, связанную с увеличением пораженной зоны [2].

Во многом определяющим моментом в складывающихся условиях видится эффективность ферментативного звена антиоксидантной системы в ранние сроки развития раневого процесса. Важной характеристикой при этом может быть уровень активности супероксиддисмутазы раневого отделяемого.

Супероксиддисмутаза является внутриклеточно локализованным ферментом. Он катализирует взаимодействие двух супероксидных анион-радикалов между собой (реакция дисмутации) с формированием в качестве продукта пероксида водорода. Биологическая роль дисмутирования супероксидов заключается в препятствии цепному характеру распространения свободнорадикальтных реакций в самом их начале. Изменение активности супероксиддисмутазы может быть связано с наличием/отсутствием субстрата супероксиддисмутазной реакции - радикалов супероксида. Согласно литературным данным, уровень указанной активной формы кислорода влияет на интенсивность функционирования фермента. Применение индукторов его образования является причиной увеличения ферментативной активности относительно дисмутирования супероксида [6, 7]. Согласно полученным нами сведениям, имеется тенденция к уменьшению активности супероксиддисмутазы раневого отделяемого. Учитывая приведенную выше информацию, имеется предположение о том, что продукция супероксидных анион-радикалов в раннюю стадию развития раневого процесса происходит в объеме, недостаточном для повышения супероксиддисмутазной активности. Обусловленность данного предположения видится в аспекте только начинающегося перемещения фагоцитов в пораженную область и, соответственно, начальном этапе работы НАДФН-оксидазы. Вполне вероятно, что последующее развитие воспалительного процесса вызовет определенный биохимический ответ в виде увеличения генерации супероксидных анионов и активности супероксиддисмутазы.

Также в рамках обсуждения причин уменьшения каталитической активности изучаемого фермента следует упомянуть его функционирование в соответствии с принципом обратной связи. Суть указанного принципа заключается в том, что пероксид водорода, который является продуктом супероксиддисмутазной реакции, вызывает снижение активности супероксиддисмутазы. 
Существенным аспектом, связанным с регуляторными механизмами модификации активности супероксиддисмутазы, является возможность изменения активности указанного энзима посредством влияния на антиоксидант-респонсивный элемент. Структурные мотивы ARE установлены для многих генов с преимущественной их локализацией в промоторных зонах [5]. Так, показано существование указанной последовательности для супероксиддисмутазы [8]. По данным литературы, пероксид водорода рассматривается в роли активатора ARE [1]. В связи с этим, недостаточность его образования определяет низкую вероятность активации ARE в условиях проведенного эксперимента.

Таким образом, тенденция к снижению активности супероксиддисмутазы в раневом отделяемом на 3 сутки после нанесения механического повреждения кожи может быть связана со следующими аспектами: 1) сниженное количество субстрата реакции; 2) функционирование принципа обратной связи; 3) воздействие на антиоксидант-респонсивный элемент, и обуславливает мнение о необходимости коррекции антиоксидантного статуса в данную стадию течения раневого процесса.

$$
* * *
$$

1. Ляхович В.В., Вавилин В.А., Зенков Н.К., Меньщикова Е.Б. Активная защита при окислительном стрессе. Антиоксидант-респонсивный элемент (Обзор) // Биохимия. - 2006. - Т. 71, № 9. - С. 1183 - 1198.

2. Окислительный стресс. Антиоксиданты и прооксиданты. / Е.Б. Меньщикова, В.З. Ланкин, Н.К. Зенков, И.А. Бондарь, Н.Ф. Круговых, В.А. Труфакин. М.: Фирма «Слово», 2006. - 556с.

3. Платонов А.Е. Статистический анализ в медицине и биологии: задачи, терминология, логика, компьютерные методы / А.Е. Платонов. - М.: Издательство РАМН, 2000. - 52 с.

4. Сирота Т.В. Новый подход в исследовании процесса ауто-окисления адреналина и использование его для измерения ак-тивности супероксиддисмутазы / Вопросы медицинской химии. 1998. Т. 45. № 3. С. 263.

5. Ткачев B.О., Меньшикова Е.Б., Зенков Н.К. Механизм работы сигнальной системы NRF2/KEAP1/ARE (Обзор) // Биохимия. - 2011. - Т. 76, № 4. - С. 502 - 519.

6. Giri S. Increases in lung prolyl hydroxylase and superoxide dis-mutase activities during bleomycin-induced lung fibrosis in ham-sters / Giri S., Misra H., Chandler D., Chen Z. // Exp. Mol. Pathol. - 1983. - № 39 (3). - P. 317 326.

7. Hassan H., Fridovich I. Physiological function of superoxide dis-mutase in glucose-limited chemostat cultures of Escherichia coli // J. Bacteriol. - 1977. - Vol. 130 (2). - P. 805 - 811.

8. Scandalios J. Oxidative stress: molecular perception and transduc-tion of signals triggering antioxidant gene defenses. // Braz. J. Med. Biol. Res. Mol. Med. Rep. - 2005. - № 38 (7). - P. 995 - 1014.

\section{Чотчаев P.М. \\ Антибиотикорезистентность и методы её преодоления}

ФГАОУ ВО « КФУ им. В. И. Вернадского

(Россия, Симферополь)

doi: 10.18411/trnio-10-2021-102

Научный руководитель: Вайман Ю.Ю.

\section{Аннотация}

Устойчивость к антибиотикам признана одной из самых серьезных проблем современной медицины. Бактериальные инфекции, устойчивые к антибиотикам, представляют собой глобальную проблему общественного здравоохранения, серьезность и масштабы которой в последние несколько десятилетий возрастают. Из-за чрезмерного использования антибиотиков наблюдается значительный рост числа микробов, которые изменяют свои гены, помогая им в развитии устойчивости к различным группам антибиотиков, особенно к антибиотикам широкого спектра действия. Сообщается, что даже антибиотики нового поколения неэффективны против таких микробов, что делает эту проблему серьезной проблемой для исследователей и, следовательно, вызывает потребность в поиске новых методов для решения этой постоянно растущей проблемы.

Сегодня от болезней, вызванных резистентными бактериями, каждый год умирает около 700 тысяч человек. В их случаях антибиотики оказались бессильны против инфекций. 